The methodological debates in German-speaking Europe (1960-1990)

Senn, Marcel

DOI: https://doi.org/10.1017/CBO9781139028578.008

Posted at the Zurich Open Repository and Archive, University of Zurich ZORA URL: https://doi.org/10.5167/uzh-61488

Book Section

Originally published at:

Senn, Marcel (2012). The methodological debates in German-speaking Europe (1960-1990). In: Musson, Anthony. Making legal history: approaches and methodology. Cambridge: Cambridge University Press, 108-117.

DOI: https://doi.org/10.1017/CBO9781139028578.008 


\section{Marcel Senn}

The methodological debates in German-speaking Europe (1960-1990) 


\title{
MAKING LEGAL HISTORY
}

\author{
Approaches and Methodologies
}

\author{
Edited by \\ ANTHONY MUSSON AND CHANTAL STEBBINGS
}


CAMBRIDGE UNIVERSITY PRESS

Cambridge, New York, Melbourne, Madrid, Cape Town, Singapore, São Paulo; Delhi, Tokyo, Mexico City

Cambridge University Press

The Edinburgh Building, Cambridge CB2 8RU, UK

Published in the United States of America by Cambridge University Press, New York

www.cambridge.org

Information on this title: www.cambridge.org/9781107014497

(C) Cambridge University Press 2012

This publication is in copyright. Subject to statutory exception and to the provisions of relevant collective licensing agreements, no reproduction of any part may take place without the written permission of Cambridge University Press.

First published 2012

Printed in the United Kingdom at the University Press, Cambridge

A catalogue record for this publication is available from the British Library

Library of Congress Cataloguing in Publication data

Making legal history : approaches and methodologies / edited by

Anthony Musson and Chantal Stebbings.

p. $\mathrm{cm}$.

ISBN 978-1-107-01449-7 (hardback)

1. Law - Historiography. I. Musson, Anthony, 1966- II. Stebbings, Chantal.

K140.M45 2012

$340.072^{\prime} 2-\operatorname{dc} 23 \quad 2011041593$

ISBN 978-1-107-01449-7 Hardback

Cambridge University Press has no responsibility for the persistence or accuracy of URLs for external or third-party internet websites referred to in this publication, and does not guarantee that any content on such websites is, or will remain, accurate or appropriate. 


\section{Introduction}

\section{ANTHONY MUSSON AND CHANTAL STEBBINGS}

On a balmy summer evening in July 2009, delegates from over twenty countries met over a glass of Pimm's in the arboretum of the University of Exeter, an event heralding the opening of the Nineteenth British Legal History Conference - three days devoted to intellectual exploration of the Making of Legal History. The approaches to and methodology of the writing of legal history was for the first time the subject of a major conference with lawyers and historians from common law jurisdictions of the world joining with their civil law compatriots to address the fundamental mechanics of their trade. A stimulating programme of some seventy presentations transcending period and subject specificity some addressing the theme by means of a case-study, others espousing a particular approach - revealed the diversity and breadth of individual scholars' approaches to legal histiography. Its Catholic nature was underlined by the delegates attending: members of the legal profession, independent scholars, university teachers, archivists, librarians, doctoral students - representatives of every facet of the world of legal history research.

This volume reflects something of the eclecticism of the conference. The chapters, which have been contributed by legal historians from around the world, include the personal approaches of leading exponents, whose extensive expertise in the area has been acquired through decades of archival research. The basic components of a successful legal historian (as Senn asserts) comprise a broad knowledge of the necessary sources and a critical mind when approaching them. Methodology itself is accorded varying recognition amongst the individual scholars, whose approaches range from the conscious to the instinctive.

Legal historians can usually be characterised by whether the focus of their research addresses internal (essentially legal or doctrinal) developments within the law, legal institutions and the legal profession or examines the influences exerted on them by external factors. Rabban points out how legal history research in the nineteenth century contemplated 
the influence of external factors on the law, but acknowledges that it was not until the later twentieth century that legal history evolved considerably as a result of researchers adopting methodologies from the social sciences, linguistics, anthropology and other cognate disciplines to interrogate their sources in the pursuit of valuable alternative perspectives. ${ }^{1}$ The transformation of legal history through new methodologies and advances in technology (giving rise to digitised, searchable resources and specialised internet sites), which Prest notes has occurred during his professional career, not only yields possibilities for a greater understanding of the subject, but has also led to a growth in the popularity of researching in legal history, particularly by colleagues in other disciplines. FrecknallHughes demonstrates how an 'interloper' from the world of business with a background in the social sciences approaches research of the fiscal revolt that confronted King John in 1215, an area of legal history that intersects with her own professional interests in the field of tax. Interdisciplinary or cross-disciplinary research is now positively encouraged in applications for funding and acknowledged in research assessment exercises. But as both Senn and Musson warn, interdisciplinarity must be understood properly as a dialogue between experts in different fields and should not simply entail an uncritical adoption of methods and sources from another discipline. Indeed, legal historians must be prepared to accept that while fresh insights are possible (such as those that can be derived from analysing visual sources) there are limitations to such an approach.

While legal history has embraced the notion that there is more to law than its formal sources, for many the law itself forms that starting and end point. The legal historian's doctrinal knowledge, critical faculties and research skills are especially brought to bear in the production of materials for use by other researchers, be they fellow legal historians, members of the legal profession or academics in other disciplines. Indeed, the important role played by the legal historian in editing legal manuscripts (notably law reports) is often overlooked or underplayed. As Baker and Brand make clear, it is not just a matter of transcription and translation, but making

1 Stuckey and Brand, for example, highlight prosopography as a method or technique that legal historians might usefully employ for achieving data on social phenomena and patterns of interaction among groups of individuals (such as members of the legal profession). A number of papers presented at the conference but not included here demonstrated the advantages and disadvantages of using methodologies derived from other disciplines, notably quantification (Penny Tucker, Rebecca Probert, David Seipp and Henry Summerson), literary theory (Lorie Charlesworth) and music theory (Adolpho Giuliani). 
the manuscript sources functional and able to be used as a springboard for further research. This involves a myriad of tasks, such as identifying surviving versions, dating manuscripts and collating texts in differing hands from various locations, correcting infelicities and pointing out discrepancies in texts, highlighting differences of detail and emphasis, identifying the names of persons and places, providing a context for cases and then marrying them up with associated records. Providing a translation of difficult areas of law that reflects contemporary practice and understanding not only requires a scholar equipped with the appropriate linguistic skills, but also demands a commanding knowledge of doctrinal matters, procedures and the personnel of the courts.

The chapters highlight the multitude of legal and non-legal sources that can be drawn on to inform the writing of legal history. They also demonstrate an appreciation of the practical as well as the methodological problems that can surround analysis and interpretation of legal sources. Researchers may be blessed with a wealth of manuscript or printed material in certain jurisdictions and for specific historical periods, but barriers to effective research - whether it be into the legal issues debated in Elizabethan law reports (Baker), Victorian law reform and law making (Stebbings), or the biographies of nineteenth-century judges (Polden) are presented by practical management of the voluminous records and the sheer time-consuming nature of manual searching (in the absence of an electronic facility). ${ }^{2} \mathrm{~A}$ dearth of available material is equally dispiriting and a considerable hindrance. Irish historians, for example, face evidentiary problems posed by the unfortunate destruction by fire of centuries of Irish public records (Donlan), while those seeking to analyse lawyers' funerary monuments or illuminated legal manuscripts are faced with the desecration, damage and destruction wreaked variously by iconoclasts, robbers and those unaware of their significance (Musson).

Legal history has always been a dynamic subject and the chapters demonstrate how the particular concerns and priorities towards it in individual countries have fluctuated. Methodological approaches adopted by scholars in Australia, New Zealand and Canada (McHugh), post-colonial Ireland (Donlan) and post-war Germany (Senn), for example, have

2 Electronic search facilities are now available for some classes of record, but in order to secure funding, the projects usually have to conform to strict parameters and not only have to be manageable and achievable, but also provide value for money. The opportunities for resource-enhancement funding formerly offered by the Arts and Humanities Research Council (UK) have now been withdrawn. 
been heavily influenced by prevailing social and political concerns. The intrusion of the physical sciences on the intellectual debate in the sixteenth and seventeenth centuries (Stuckey) and the social sciences in the twentieth (Rabban) undermined the prevailing dominance that historical analysis of the law enjoyed in the past and effectively relegated legal history to the category of a sub-discipline. Its slightly uneasy position, nestling between law and history, remains a potential source of tension and signifier of professional difference between academic lawyers and academic historians (Prest). As Heirbaut wryly comments, a perception still pertains amongst legal historians of the need to justify their historical work to colleagues in law faculties and seek the approbation of the legal profession as to its value. Stuckey, however, views legal history more positively as a hybrid discipline since exponents of law and history both seek representation of 'authentic' phenomena based on critically analysed evidence.

The crux lies in the significance placed on law and history by the various interested parties and how historical research in the law is understood and used. In this respect, several chapters tackle the relationship between legal historians and the legal profession. They do not investigate the respective positions of legal historians in different countries or the relative esteem accorded them by the profession, but they do highlight both the blurred boundaries and the differences of emphasis between what lawyers and legal historians want to know and how they portray the past, especially the posthumous contributions of members of the legal profession (Prest, Polden, McHugh, Rabban). The lawyer in search of 'truth' requires certainty and the best, most convincing evidence underscored with appropriate justification or legal authority. Legal historians, however, can show that legal 'truth' is no more in the past than in the present and that a historical framework must take account of a number of different legalities. Indeed, they embrace a different kind of truth - a historical 'truth' that accepts uncertainty and appreciates the contingency of legal authority and the sometimes shaky foundations of the law (which lawyers rarely admit). In examining the significance of manuscript case notes in legal practice, Oldham demonstrates how there were real-life practical dilemmas in the eighteenth century with regard to the quantity and quality of law reports and how reliant the justice system and legal profession were (and have become) upon a legal source that was moulded by chance factors. Similarly, Ireland and Polden go where lawyers fear to tread, exposing not only the elements of chance, but also the practical circumstances, the interaction of personalities and the role of incompetence 
and other human failings (in the people behind the law) that proliferate and combine to affect the making of case law and professional reputations. It is, moreover, the attitude of the legal profession (and through them, the justice system) towards the legal past (and the presence of law in the past) that signifies a divergence from legal historians, namely when the historical use of and role of law is harnessed for resolution by the standards and authority of today's law in contemporary courts and tribunals (especially, as McHugh shows, in the relation to the land claims of indigenous peoples).

The notion that the purpose of legal history is to understand, restate and reform the law purely on the basis of study of the evolution of doctrine is shown to be limited and dated. As Stebbings concludes, a proper evaluation of the formal sources of law in itself forces a researcher of historical developments in law in the Victorian age (and probably other periods too) to break out of their traditional approach to doctrinal legal history. Moreover, the chapters in this volume reveal that the direction in which legal history is travelling is much more 'how the law works' rather than the traditional 'what the law is', showing a concern for both 'law in action' and 'legal outcomes' (the final decisions emerging from the legal process), together with an emergent field of 'how the law is perceived and received' (and the impact of that on its operation). This does not mean that internal legal history is no longer of any value. While it is fashionable to pursue the external influences on law, nevertheless as Heirbaut maintains, a thorough evaluation of the legal context should not be ignored. This, indeed, is a special task for the legal historian, whose training enables him or her to understand the practical as well as the theoretical operation of the law. As several contributors indicate, it is also important to be aware that what is found through investigation of the legal past is often merely a guideline to what happened, a gloss on the mixed and (to the ordered legal mind) wholly unsatisfactory muddle of reality.

The chapters in this volume are arranged thematically rather than chronologically and provide initially an assessment of sources and approaches to doctrinal legal history, then an examination of comparative methods from various national and historical standpoints, followed by an evaluation of a range of interdisciplinary approaches to the sources for legal history. These chapters attest to the inestimable value that can be placed on accumulated experience - from familiarity with particular source material through time spent in the archives and from the habit of critical legal and historical analysis - and demonstrate that much of the 
burden of undertaking legal history research cannot easily be delegated to a research assistant as the science (or social science) model would have us do in order to obtain the money needed to pursue research in the subject today. They also celebrate the diversity present in legal history writing and show a robust underlying discipline to legal history research across the world. Its exponents do not advocate an all-purpose, 'one-sizefits-all' methodology, nor do they avow that one particular technique is more correct than another, though recommendations are made as to best practice in certain fields and appropriate approaches for answering particular legal research questions. Legal historians should not be afraid to adopt a multitude of approaches and experiment in finding different ways to ascertain the 'truth' of the legal past. Continued cooperation across national boundaries and legal traditions and across the different cognate disciplines is a research imperative that the contributors duly acknowledge. Use of a comparative approach to provide a 'strand of cosmopolitanism' and explore the complexity of historical and legal traditions is advocated by Ibbetson (and others), ${ }^{3}$ both to avoid excessive national insularity and to explore the relationship between law and the extra-judicial and extra-legal, especially where it is not easily disentangled from official law and established legal order (Donlan).

Finally, the editors would like to express their grateful appreciation to those organisations which generously sponsored aspects of the conference that gave rise to chapters in this volume (the Legal History Forum at the Oxford Faculty of Law; William S. Hein \& Co.; the Journal of Legal History; and the Royal Historical Society); and thanks to all participants, whose pertinent and insightful questions afforded a stimulating debate both in and outside the conference hall, which itself is the life of making legal history.

This volume is offered in memory of Brian Simpson, who was to have attended as a plenary speaker, but was forced to withdraw through sudden ill health. His work has been an inspiration for many generations and his death in January 2011 represents a tragic loss to legal history.

3 The editors note the formation of the European Society for Comparative Legal History, whose inaugural conference was held in the University of Valencia in July 2010. Several contributors to the volume were present and David Ibbetson's chapter was delivered as a paper there. 


\title{
The methodological debates in German-speaking Europe (1960-1990)
}

\author{
MARCEL SENN*
}

\section{Why methodology?}

In the early 1960s, there erupted what is now known in Germany as 'the methodological debates' of the social sciences. The debates were heavily contested, and the need for methodological reflection was not a given at the time. Disparaging comments were often heard along these lines: methodological debates serve no purpose; they distract from real research; they are of theoretical interest only as they deal in mere abstractions.

With almost fifty years of hindsight, we have seen many positions defended in the humanities, covering the full range from controversial to flaky. It might be more plausible today than it was then to assert that many trends could actually be in need of some sort of method. To Polonius's famous statement in Shakepeare's Hamlet, 'Though this is madness, yet there's method in't!' we might respond: if only it were so!

Taking the lead from its meaning in ancient Greek, 'having a method' means having a direction leading to a goal. Indeed, the ancient Greek word $\mu \dot{\varepsilon} \theta \circ \delta \circ$ contains this idea. Implicit is that the goal is shared among human actors. Applied to the humanities, having a method means that the directions and goals - that is, the processes as a whole - are transparent to the participants, and the results from such processes will receive general recognition of validity only when clarity is achieved.

The orientation towards shared goals and directions faces a variety of difficulties. Humanities and cultural studies are concerned with statements and distinctions about human endeavours in their temporal and local contexts. By contrast, natural sciences are concerned with invariable laws of nature and their manifestations. In both cases, shared standards at the level of methods produce clarity in the chosen approaches and 
directions, which in turn establish validity of intellectual results. While the rigours of natural sciences would not be reasonable in the humanities, we can and must adhere to high standards of plausibility by subjecting arguments and resulting claims to ongoing criticism. For this reason, methodological debates are the true sign of a modern concept of science.

\section{A zenith of methodological debates in German legal history ${ }^{1}$}

On the continent, in particular in German-speaking Europe, we have faced general methological debates in the humanities. The methodological debates reached their zenith between the 1960s and 1990s. They also influenced law in general and legal history in particular. The present chapter will focus on this particular aspect.

One of the last congresses of legal historians with the focus on methodological debates took place in $1996 .^{2}$ Since then, things have become distinctly quiet in legal history. The result was to have always several methodological ways, however, any methological reflection was an advantage in any case and absolutely necessary to do serious research in legal history.

As of the mid 1990s, the debates became fewer but they still continue to influence research in legal history. The debates encouraged a general intellectual opening, and they led to new questions being asked, informed by other disciplines. The general opening also led to experimentation with new research methods on historical materials. On the flipside, the debates produced methodological extremes, too, that operated on mixtures of trendy theories or preached the purity of one single theory.

1 M. Senn, 'Rechtswissenschaft und Geschichte' in M. Anderheiden and S. Kirste (eds.), Interdisziplinarität in den Rechtswissenschaften - Innen- und Aussenperspektiven (Tübingen, Mohr Siebeck, 2012); M. Senn, Rechtshistorisches Selbstverständnis im Wandel. Ein Beitrag zur Wissenschaftstheorie und Wissenschaftsgeschichte der Rechtsgeschichte (Zurich, Schulthess, 1982); D. Klippel, Juristische Zeitgeschichte. Die Bedeutung der Rechtsgeschichte für die Zivilrechtswissenschaft (Giessen, Brühl, 1985); Gerhard Oexle, 'Rechtsgeschichte und Geschichtswissenschaft' in D. Simon (ed.), Akten des 26. Deutschen Rechtshistorikertages Frankfurt a. M., 22. bis 26. September 1986 (Frankfurt a. M., Klostermann, 1987), 77-107; R. Ogorek, 'Rechtsgeschichte in der Bundesrepublik (1945-1990)' in D. Simon (ed.), Rechtswissenschaft in der Bonner Republik. Studien zur Wissenschaftsgeschichte der Jurisprudenz (Frankfurt a. M., Suhrkamp, 1994), pp. 12-99.

2 The conference's transcript had been edited by P. Caroni and G. Dilcher, Norm und Tradition. Welche Geschichtlichkeit für die Rechtsgeschichte?/ Fra norma e tradizione. Quale storicità per la storia giuridica? (Cologne, Weimar and Vienna, Böhlau, 1998). 


\section{Revolving basic conditions}

The situation at the universities before and after 1968

Several events and trends shaped the methodological debates on legal history in German-speaking Europe. Society at large and the universities in particular were involved with the 1968 movements.

The social fabric underwent radical change and generational conflict set the tone: a peace-seeking young generation opposed the Vietnam war, searched for social justice, and revolted against their fathers and teachers who had spent their formative years in an altogether different experience, that of World War II. In the face of these conditions, the idea arose that legal history as a discipline of law should put the fundamental issues of human justice centre stage and from this perspective investigate the historic circumstances of law in society.

Related to this point is the observation that legal history as part of law became a subject in need of justification. In the course of the social and political upheavals, the traditional German notion of higher education (Bildung) came apart and questions of utility began to be asked of subjects that previously had been accepted as an unquestioned part of Bildung. Suspicions were raised that legal history represented mere dead weight or aesthetic decoration in the practice-oriented study of law and statutes. Some form of utility had to be found for the subject, or else it would be relegated to a mere preface or footnote of law. Proposals were made, in particular by the New Left, according to which legal history should place itself in the tradition of the Enlightenment, seek to expose the historic contingency of Law, and thereby impact on the scientific discourse of law.

At the same time as the deliberation as to the stance to be taken within the social and political discussions by the humanities in general, and in particular, legal history, there was a concrete methodological offer by Hans-Georg Gadamer in 1960. His hermeneutical programme established a concept wherein the different perspectives afforded by legal, historical, social and political aspects were prismatically concentrated in a single focus. Gadamer's grand opus, Truth and Method, ${ }^{3}$ therefore, imparted momentum to a broad discussion of the role of methodology in the humanities.

Gadamer argued that the major epistemic achievement of the humanities is understanding, or comprehension and interpretation (Verstehen), which in turn is an applicative act that is more sustained than limited in 
essential ways by the historic horizon of the interpreting subject. Others followed, including Jürgen Habermas and the Frankfurt School. They took the problem of having an essential point of view to imply that truth claims in the humanities required critical reflection of underlying, implicit or even subconscious assumptions. These critics, largely on the political left, focused on the limiting aspects of the interpreting subject's historic horizon, whereas Gadamer insisted on its epistemically and even ontologically constitutive aspects. In the methodological debates, Gadamer's hermeneutics and the Frankfurt School's Critical Theory ${ }^{4}$ were both in opposition to their shared strawman, a limited notion of 'positivistic methodology' according to which rigid rules, approaches and protocols were the only sources of truth, even in the humanities. Some of these themes seem outdated from today's vantage point, but some have also left a mark on today's methodological awareness.

\section{The nucleus of the debates}

Against this polarising historical backdrop that lasted into the 1970s, humanities and cultural studies fell into two camps along the political leftright spectrum, and accordingly historiography divided into bürgerlicher (bourgeois) historicism on the one hand, and Marxist approaches on the other. In response to the methodological criticisms based on Gadamerian hermeneutics and Frankfurt Critical Theory, social scientists were called to examine the social and political assumptions underlying their investigations of legal history, from bürgerliche topics such as family and property to New Left topics such as the reconstruction of legal practice in a dialectical historic framework.

These developments resulted in two opposite methodological paradigms of legal history. In West Germany, this controversy struck a particularly sensitive chord as a result of the aftermath of World War II. The country was divided over the politically charged questions of how to approach communist East Germany, and even more so over how to face up to the Nazi past. Political alignment tinged all discussions, including those of methodology in legal history. Even though approaches based on 'dialectics' were widely perceived as the most consistent and promising, there was a vigorous discussion in legal history that involved taking political sides on the left-right spectrum.

4 The Kritische Theorie of the Frankfurt School is not to be confused with Anglo-Saxon literary criticism. 


\section{The three basic models 5}

In spite of the political polarisation of the landscape, there was room for a third historiographic model, one that drew on the social sciences as well as the historicist and Marxist approaches. The three models can be characterised as follows.

The first model, historicist legal history, aimed at producing narratives composed of singular events, without claim to generality or law-like explanation. In this model one can distinguish three sub-types: the first sub-type consisted of a dogmatic interpretation of sources that describes history as a linear evolution. In this view legal history is just a preface to the comprehension of law. This conception had politically controversial results because it would describe the German National Socialist state as a formal rule of law. On the face of it, this was not entirely wrong from a dogmatic point of view. The second sub-type embraced the contemplative interpretation of sources in relation to other objective matters of historical relevance. It aimed to reconstruct a historic reality with claims to generality inspired by the natural sciences and their laws of nature. As for political implications, in this view the National Socialist state was not a formal rule of law because it contradicted justice and fairness in society and state. The third sub-type was the most liberal conception in the historicist tradition of legal history. Its approach was 'applicative' in the sense of Gadamerian hermeneutics; it considered history as a construction, and it was progressive in its requirement that authors account for the intentions and assumptions underlying their interpretations. Its interpretation of the National Socialist state used formal qualities descriptively but denied the possibility that this could be a state of justice.

Second, in opposition to the bürgerliche historicist models (mentioned further above), stood the Marxist models of legal history, founded on 'dialectic materialism'. This view postulated economics as the driver of all matters of social, political and historic importance, the struggle between the social classes as underlying all historic developments, and the eradication of oppression of one class by another as the ultimate goal of social evolution. Law in this conception is a derivative of the 'dialectical' process whereby the oppresser class imposes its definition of law on all of society. National Socialism, in this view, was a relic of the notion that

5 See M. Senn, Rechtshistorisches Selbstverständnis im Wandel. Ein Beitrag zur Wissenschaftstheorie und Wissenschaftsgeschichte der Rechtsgeschichte (Zurich, Schulthess, 1982), pp. 118-175. 
oppression is the basis of all society. The question of the rule of law is, in this case, irrelevant as it is merely an expression of the Marxist notion of oppression.

Finally, the third model of legal history integrated general aspects of social development in historicist approaches by drawing on the social sciences, in particular on sociology, psychology and political science. It aimed at a notion of history that comprehends the development and functioning of society in general. From Marxist historiography, on the other hand, it adopted a concern for issues of social justice. Both the borrowing of social science approaches and the focus on social justice promised a type of analysis of historic materials that rises above the mere narration of historic detail and produces statements of general and comprehensive validity. The National Socialist state could be described psychologically as the use of the rule of law to mask the brutality of dictatorship with the goal of usurping total power.

\section{The end of the debates in the mid 1990s}

The methodological debates in legal history faded in the 1990s. Some contributing factors may have been the following. After a long period of intense argument there was a general exhaustion as well as a lack of interest shown by the younger generation. The fall of the Iron Curtain and the opening of the borders between East and West mitigated the original conflicts that had driven the formation of the methodological programmes from the background. A third factor may have been of an institutional nature at universities, the gradual vanishing of chairs in legal history. Between 1980 and 2007/2008 their number shrank by 20 per cent. ${ }^{6}$ This fact alone may have discouraged young aspiring scholars from engaging in controversies and motivated them to deliver 'solid work' instead.

However, not all these facts and circumstances were influential. The desire to work on 'solid science' led some to flee the methodological debates for safe havens, such as Niklas Luhmann's 'System Theory'. This theory was taken so seriously that it became a doctrine, and its adherents formed what could appropriately be called a scientific sect. To them, System Theory was the only key that would turn the humanities into proper 
sciences. The adoption of System Theory in legal history features two developments: on the one hand, the establishment of a 'fundamentalist' group of representatives that tries to achieve confessional purity; ${ }^{7}$ on the other hand, the development of a 'syncretistic' group that freely mixes System Theory with other theories such as the sociology of Pierre Bourdieu and/or the structuralism and psychology of Michel Foucault. Studies in legal history that are inspired by these fads tend to be somewhat deflating in that they mostly boil down to rather conventional descriptions of historical facts, albeit obscured by a peculiar vocabulary. Whether any of these two movements will succeed in our field is questionable, ${ }^{8}$ and they may have passed their zenith by now.

\section{Focusing on England}

As an outsider to British legal history, I could not presume to speak for methodological debates (if any) in England. You, my readership, would have to conduct this discussion on the basis of your own specific conditions and scientific traditions.

All the same, I shall briefly comment on the British circumstances from my particular perspective. There might be some benefit in attempting to build bridges between two very different traditions in legal history. I would like to compare the English and the Continental programmes, and to this end I will distinguish two aspects: those of research methodology and those of legal education.

Legal education has been very. different in England and Germanspeaking Europe for a long time, dating back before the nineteenth

7 M. T. Fögen, 'Rechtsgeschichte - Geschichte der Evolution eines sozialen Systems. Ein Vorschlag', Zeitschrift des Max-Planck-Instituts für europäische Rechtsgeschichte, 1 (2002), 14-19; M. Amstutz, 'Rechtsgeschichte als Evolutionstheorie', Zeitschrift des Max-PlanckInstituts für europäische Rechtsgeschichte, 1 (2002), 26-31; M. Aschke, 'Evolutionstheorie für das Recht der Marktgesellschaft', Zeitschrift des Max-Planck-Instituts für europäische Rechtsgeschichte, 2 (2003), 25-38; R. Stichweh, 'Systemtheorie und Geschichte' in F. Welz and U. Weisenbacher (eds.), Soziologische Theorie und Geschichte (Opladen, Westdeutscher Verlag, 1998), pp. 68-79. Some critical remarks on the 'System Theory' by P.-U. Merz-Benz and G. Wagner (eds.), Die Logik der Systeme. Zur Kritik der systemtheoretischen Soziologie Niklas Luhmanns (Constance, UVK, 2000) as well as for the facility to adapt it within legal history by A. Thier, 'Systemtheorie und kirchliche Rechtsgeschichte' in R. Helmholz et al. (eds.), Grundlagen des Rechts. Festschrift für Peter Landau zum 65. Geburtstag, Rechts- und Staatswissenschaftliche Veröffentlichungen der Görres-Gesellschaft, vol. 91 (Paderborn, Munich, Vienna and Zurich, Schöningh, 2000), 1065-102.

8 T. S. Kuhn, The Structure of Scientific Revolutions (University of Chicago Press, 1962). 
century. ${ }^{9}$ As I see it, Continental legal education at universities focuses on theory and critical reflexion of law and its practice. ${ }^{10}$ During student training, we de-emphasise comprehensiveness of the material taught, and, while we do teach 'knowledge', greater emphasis is being placed on the development of the critical faculties. ${ }^{11}$ By comparison, British legal education differentiates more clearly (than we do) between a theoretical and a practical part of education. At university, students learn the system of precedents as a theoretical way to acquaint themselves with the function of law, whereas at inns or law firms they learn the practice of consultants or attorneys-at-law to become successful barristers or solicitors.

We could debate the pros and cons of the two systems of legal education and ask which leads to greater expertise in analytical thinking, reasoning and critical faculties. Both systems have their specific qualities, and in the end they lead to similar results. Legal history, however, could benefit if it were more than the passing on of the knowledge of older ways and the mere narration of how legal systems developed their modern forms. Legal history could convey a deeper sense of how to approach historic material with a critical sense for its backward conditionality, its forward relation to subsequent developments, and its embeddedness in historic, social and local contexts. Such examination of historic materials not only conveys knowledge but also, more importantly, fosters autonomous critical skills of historic and contextual reconstruction that transcends legal history and is likely to benefit all students of law. Therefore, improving legal education and history of law would require that legal historians engage

9 M. Senn, 'Legal Education in England and the German Historical School of Law in the Nineteenth Century' in A. Lewis, P. Brand, P. Mitchell (eds.), Law in the City. Proceedings of the Seventeenth British Legal History Conference, London, 2005 (Dublin, Four Courts Press, 2007), pp. 249-61.

10 W. Ernst, 'Gelehrtes Recht - Die Jurisprudenz aus der Sicht des Zivilrechtslehrers' in C. Engel and W. Schön (eds.), Das Proprium der Rechtswissenschaft (Tübingen, Mohr Siebeck, 2007), pp. 3-49.

11 For instance, I train students to examine anonymised historical texts and to probe their substance beneath their historic detail and local colour. I thereby develop and instil a critical sense in my students for the historic continuity as well as contingency of our modern legal thinking which otherwise would be too easily taken for granted as ultimate truth. See M. Senn, 'Die Bewegungsfähigkeit des Interpreten. Ein Beitrag zur kulturwissenschaftlichen Pädagogik der Textinterpretation in der Rechtsgeschichte' in P. Stoellger (ed.), Genese und Grenze der Lesbarkeit (Würzburg: Königshausen \& Neumann, 2007), pp. 75-93; www.rwi.uzh.ch/lehreforschung/alphabetisch/senn/cont/ 080630_Bewegungsfaehigkeit_des_Interpreten. pdf. As to training for the practice of law, those students who wish to become lawyers take a special exam to become solicitors and barristers, as we do not distinguish between the two roles. 
in a discussion of their methodologies, and this brings us back full circle to the main topic of this chapter.

\section{Dealing with reflection and methodology}

As I conceive it, there are two basic components to a sucessful legal historian: broad knowledge of materials, and a critical mind with regard to approaches to these materials. These two qualities set the stage for an autonomous scholar who is able to analyse and reconstruct historic realities. Which approach a scholar tries first is of lesser importance than a critical attitude. For my part, over time I have developed considerable scepticism towards holistic approaches that tend to match historic realities to theory, as opposed to the other way around. In a German context, Niklas Luhman - mentioned above - comes to mind.

My preference is for clearly reflected bottom-up approaches that stay near ground level and closely hug the historic material. In my experience it is the exposure to the sources and the training of one's critical faculties on them that contributes to the general legal education of students and the advancement of legal history as a field. For the scholar, it is of the essence to preserve a critical attitude towards theories and methodologies, both one's own and those of others. As a corollary, an ongoing debate of methods is a necessity in our field. Reality is always multifaceted and any theory is just a partial reflection of reality at best. Those of us who have practised at a court, a law firm or a government agency know quite well the meaning of reconstructing the facts of a case, and we are struck by how fragile and precarious each and every reconstruction remains even after our best efforts. This awareness of fragility is something I personally acquired in legal practice, and I recommend extensive legal practice as part of the education of legal historians.

The fragility of the reconstruction of past realities as well as of any case we deal with at court is the reason why I believe that we legal historians are well advised to distance ourselves from holistic approaches and theories. If we take generalising theories at face value, we tend to get lost in ideological territory and intellectual arbitrariness, as exemplified by some of the positions taken in the methodological debates in German-speaking Europe.

However, my scepticism towards holistic theories should not be taken as a complete refusal to listen to theories. Theoretical approaches can be helpful in making sense of certain historic materials, if these approaches are used as heuristics rather than evidence. A critical approach to 
historical sources is characterised by the awareness that all sources allow us to reconstruct just a small fraction of the complexity of a past reality. The necessary simplifications and points of view inherent in any particular analysis always leave room for more than one defensible interpretation compatible with the sources, and insofar they do not contradict each other but rather illuminate different aspects and possibilities of past realities. Hence, multiplicity of reasonable interpretation does not mean arbitrariness, subjectivity, or mere convention; multiplicity of interpretation is entirely compatible with high intellectual standards of argumentation and progress of the field.

Finally, I would like to put my finger on the delicate subject of using methods from other disciplines. In light of past experience, I am rather sceptical when legal historians employ imported methods from other fields on their own. This, I think, is a misunderstanding of interdisciplinarity. An interdisciplinary spirit means a dialogue between experts, not a faddish adoption of each other's methods. Protected by a welldeveloped critical sense towards theories and methods in general, we may have the best promise of approaching, if not reaching, anything that could be called historical objectivity. Under this same protection we may also be able to cooperate across national boundaries and legal traditions. 